ORIGINAL

\title{
Blood gas analysis in Mangalarga Marchador horses with colic
}

\author{
Análisis de gases sanguíneos en caballos Mangalarga Marchador \\ con cólico
}

\author{
Tiane F. Castro, ${ }^{1}$ M.Sc, Félix González, ${ }^{1 *}$ Ph.D. \\ ${ }^{1}$ Universidade Federal do Rio Grande do Sul, Faculdade de Veterinária, Av. Bento Gonçalves, 9090, \\ Porto Alegre, 94540-000, Brasil.*Correspondencia: felixgonzalez.ufrgs@gmail.com
}

Received: April 2014; Accepted: November 2014.

\begin{abstract}
Objective. This study aims to distinguish blood gas changes in horses with colic syndrome in which small or large intestine is affected. Materials and methods. Thirty Mangalarga Marchador horses were assessed, divided into groups according to the affected intestinal segment in episodes of colic syndrome (ECS): a group $(\mathrm{N}=10)$ of horses suffering from ECS with lesions only in the small intestine, a group $(\mathrm{N}=10)$ of horses suffering from ECS with lesions only in the large intestine and a group $(\mathrm{N}=10)$ of healthy horses (control). All the animals with ECS were submitted to exploratory laparotomy in order to establish the intestinal segment affected. Blood samples were collected by venipuncture, before surgical procedure to determine sodium, potassium, chloride, urea, glucose, hematocrit, hemoglobin, $\mathrm{pH}$, carbon dioxide partial pressure, total carbon dioxide concentration, bicarbonate, base excess and anion gap. Results. No significant changes were found in plasma levels of $\mathrm{Na}^{+}, \mathrm{K}^{+}, \mathrm{Cl}^{-}, \mathrm{pCO}_{2}$ and anion gap in any type of ECS. Horses with small intestine injuries presented higher levels of $\mathrm{tCO}_{2}$, urea and bicarbonate compared to those with large intestine injuries and to the control group, as well as higher levels of glucose and base excess than the control group. Conclusions. Horses with colic syndrome bearing small intestine injuries show wider variations in the blood gas parameters than horses with large bowel lesions.
\end{abstract}

Key word: Acid-base imbalance, electrolytes, large intestine, small intestine (Source:CAB).

\section{RESUMEN}

Objetivo. El presente estudio tuvo como objetivo diferenciar las alteraciones de gases sanguíneos que ocurren en casos de cólico equino con comprometimiento en intestino delgado o grueso. Material y métodos. Fueron evaluados 30 caballos Mangalarga Marchador con sindrome de colico equino (SCE) divididos en grupos según el segmento intestinal afectado con episodios de cólico: un grupo de animales $(\mathrm{N}=10)$ con SCE solo en el intestino delgado, un grupo $(\mathrm{N}=10)$ con SCE solo en el intestino grueso y un grupo $(\mathrm{N}=10)$ de animales sanos (control). Todos los animales fueron sometidos a laparotomía exploratoria para identificar el segmento intestinal afectado. Muestras de sangre fueron recogidas antes del procedimiento quirúrgico para determinar la concentración: sodio, potasio, cloro, urea, glucosa, hematocrito, hemoglobina, $\mathrm{pH}$, presión parcial de dióxido de carbono, concentración total de dióxido de carbono bicarbonato, exceso de base y anión gap. Resultados. 
No fueron observadas alteraciones significativas en los niveles plasmáticos de $\mathrm{Na}^{+}, \mathrm{K}^{+}, \mathrm{Cl}^{-}, \mathrm{pCO}_{2} \mathrm{ni}$ anión gap, independiente de la localización intestinal del SCE. Los equinos con lesiones en el intestino delgado presentaron niveles superiores de $\mathrm{tCO}_{2}$, urea y $\mathrm{HCO}_{3}{ }^{-}$con relación a los que tuvieron lesiones de intestino grueso y al control, así como niveles superiores de glucosa y de exceso de base con relación al control. Conclusiones. Equinos con síndrome de cólico con lesión de intestino delgado presentaron variaciones más amplias en los parámetros de gases sanguíneos que equinos con cólico afectados en el intestino grueso.

Palabras clave: Ácido-básico, desequilibrio, electrolitos, intestino delgado, intestino grueso (Fuente: $C A B)$.

\section{INTRODUCTION}

Equine colic syndrome (ECS) or acute abdomen is a multifactorial syndrome that results in deep abdominal pain in horses, with a diversified etiology varying from excessive gas yielded from feed fermentation to obstruction and bowel torsion, commonly requiring surgical intervention (1). The diagnosis of ECS is relatively easy considering the features of the abdominal pain, which cause changes in animal behavior, but its etiology is yet a challenge for veterinarians, especially in the definition of the affected intestinal segment.

The use of supporting diagnosis tools, like hemogram, blood gas analysis and biochemical profile can give information concerning inflammatory focuses, dehydration or hipovolemia, toxemia, and electrolytic, acidbase or metabolic imbalances, providing a more precise diagnosis, an adequate treatment and a more accurate prognosis (2).

Practically all disorders affecting the gastrointestinal tract lead to imbalances in blood $\mathrm{pH}$, bicarbonate, sodium, potassium and chloride that may be immediately corrected to avoid the risk of death. The acid-base and hydro-electrolytic evaluation, as well as the blood gas condition allow choosing the more appropriated treatment for the animal with colic syndrome. Blood gas analyzes the partial $\mathrm{O}_{2}$ and $\mathrm{CO}_{2}$ pressure as well as bicarbonate and $\mathrm{pH}(3)$, becoming the most appropriate method for evaluating the acid-base balance of organic fluids and their probable disturbances (4). Blood gas evaluation is a very useful parameter for determining the severity of the colic syndrome and also may helps in the identification of bowel lesions (1).

The present work had the aim of evaluating changes in blood gas parameters in Mangalarga Marchador horses suffering from colic syndrome, discriminating the intestinal bowel affected, in order to obtain additional tools for clinical and surgical assessment.

\section{INTRODUCCIÓN}

El síndrome de cólico equino (SCE) o abdomen agudo es un síndrome multifactorial que ocasiona dolor abdominal intenso en los caballos con una etiología variada entre el exceso de gas producto de la fermentación alimenticia hasta obstrucción y torsión intestinal, lo que comúnmente requiere de una intervención quirúrgica (1). El diagnóstico de SCE es relativamente fácil teniendo en cuenta las características del dolor abdominal que causa cambios en el comportamiento del animal, pero su etiología es todavía un reto para los veterinarios, especialmente la definición del segmento intestinal afectado.

El uso de herramientas de diagnóstico, como hemogramas, gasometría arterial y perfil bioquímico, pueden ofrecer información sobre focos inflamatorios, deshidratación o hipovolemia, toxemia y desequilibrios electrolíticos, acido-base o metabólicos, proporcionando un diagnóstico más preciso, un tratamiento adecuado y un pronóstico más exacto (2).

Prácticamente todos los trastornos que afectan el tracto gastrointestinal conducen a desequilibrios en el pH sanguíneo, bicarbonato, sodio, potasio y cloruro que pueden corregirse inmediatamente para evitar el riesgo de muerte. La evaluación del equilibrio hidroelectrolítico y ácido-base, así como la condición de gases sanguíneos, permiten elegir el tratamiento más apropiado para el animal con síndrome de cólico. Por medio de los gases arteriales se analiza la presión parcial de $\mathrm{O}_{2}$ y $\mathrm{CO}_{2}$ así como el bicarbonato y $\mathrm{pH}$ (3), convirtiéndose en el método más apropiado para evaluar el equilibrio acido-base de los fluidos orgánicos y sus probables perturbaciones (4). La gasometría arterial es un parámetro muy útil para determinar la severidad del síndrome de cólico y puede también ayudar en la identificación de lesiones intestinales (1).

El presente estudio tuvo como objetivo evaluar los cambios en los parámetros de gases sanguíneos en caballos Mangalarga Marchador con síndrome de cólico, haciendo una diferenciación del intestino afectado, con el fin de obtener herramientas 


\section{MATERIAL AND METHODS}

Animals. All the horses in this work were selected following criteria of clinical signs of colic syndrome at a referred veterinary hospital. The animals were Mangalarga Marchador horses from 3 to 15 years old, from both sexes ( 18 males and 12 females). The location of the intestinal section affected was established through laparotomy procedure.

The animals were organized in three groups as follows: animals with lesions only in the small intestine $(\mathrm{N}=10)$; animals with lesions only in the large intestine $(\mathrm{N}=10)$; and healthy animals (control group) $(\mathrm{N}=10)$.

Sampling and analysis. Blood samples ( $2 \mathrm{~mL})$, from the jugular vein, were collected anaerobically through heparinized tubes (Becton Dickinson, São Paulo, Brazil) for blood gas analysis before the surgical procedure. The analysis was done using a portable analyzer (I-Stat 1 , Abbott, Princeton, USA), with specific cartridges following the manufacturer's instructions. The equipment was automatically calibrated before the samples analysis. The cartridge used was EC8+, which is able to determine sodium $\left(\mathrm{Na}^{+}\right)$, potassium $\left(\mathrm{K}^{+}\right)$, chloride $\left(\mathrm{Cl}^{-}\right)$, urea, glucose, hematocrit, hemoglobin, $\mathrm{pH}$, partial carbon dioxide pressure $\left(\mathrm{pCO}_{2}\right)$, total carbon dioxide concentration $\left(\mathrm{tCO}_{2}\right)$, bicarbonate $\left(\mathrm{HCO}_{3}\right)$, base excess (EB) and anion gap (AG).

Statistical analysis. Statistical analysis was performed through Anova test, relating the intestinal bowel affected with the studied parameters. Quantitative variables (mean and standard deviation) were analyzed using the Tukey test, considering a significance level of $5 \%$, using the Instat program.

\section{RESULTS}

The values obtained for hemogasometric analysis according to the affected intestinal section are showed in table 1.

Plasma levels of $\mathrm{Na}^{+}, \mathrm{K}^{+}, \mathrm{Cl}^{-}, \mathrm{pCO}_{2}$ and anion gap did not show any significant alteration $(p>0.05)$ no matter which was the affected bowel segment. Glucose concentration was higher in $65 \%$ of the animals suffering from ECS, compared to the reference values (maximum reference value: $115 \mathrm{mg} / \mathrm{dL}$ ). Glucose and urea concentrations were higher $(p<0.05)$ in the group of horses with small intestine lesions compared to animals with large intestine lesions and to control animals. The values of hematocrit and hemoglobin did adicionales para realizar una evaluación clínica y quirúrgica.

\section{MATERIALES Y MÉTODOS}

Animales. Todos los caballos en este estudio fueron seleccionados siguiendo los criterios de los signos clínicos del síndrome de cólico en un hospital veterinario. Los animales eran caballos Mangalarga Marchador de 3 a 15 años de edad, de ambos sexos (18 machos y 12 hembras). La ubicación de la sección intestinal afectada fue establecida por medio un procedimiento laparoscópico.

Los animales fueron organizados en tres grupos de la siguiente manera: los animales con lesiones únicamente en el intestino delgado $(\mathrm{N}=10)$; los animales con lesiones únicamente en el intestino grueso $(\mathrm{N}=10)$; y los animales sanos (grupo de control) $(\mathrm{N}=10)$.

Muestreo y análisis. Se tomaron muestras de sangre ( $2 \mathrm{~mL}$ ) de la vena yugular anaeróbicamente a través de tubos heparinizados (Becton Dickinson, Sao Paulo, Brasil) para el análisis de gases arteriales antes del procedimiento quirúrgico. El análisis se realizó utilizando un analizador portátil (I-Stat 1, Abbott, Princeton, Estados Unidos) con cartuchos específicos y siguiendo las instrucciones del fabricante. El equipo fue calibrado automáticamente antes del análisis de las muestras. El cartucho utilizado fue un $\mathrm{EC} 8+$, por medio del cual es posible determinar la concentración de sodio $\left(\mathrm{Na}^{+}\right)$, potasio $\left(\mathrm{K}^{+}\right)$, cloruro $\left(\mathrm{Cl}^{-}\right)$, urea, glucosa, hematocrito, hemoglobina, $\mathrm{pH}$, presión parcial de dióxido de carbono $\left(\mathrm{pCO}_{2}\right)$, concentración total de dióxido de carbono $\left(\mathrm{tCO}_{2}\right)$, bicarbonato $\left(\mathrm{HCO}_{3}\right)$, exceso de base (EB) y brecha aniónica (BA).

Análisis estadístico. El análisis estadístico fue desarrollado mediante la prueba Anova, en relación con el intestino afectado con los parámetros estudiados. Las variables cuantitativas (media y desviación estándar) fueron analizadas mediante la prueba de Tukey, utilizando un nivel de significancia del $5 \%$ y el programa Instat.

\section{RESULTADOS}

En la tabla 1 se muestran los valores obtenidos a partir del análisis de hemogasométrico según la sección intestinal afectada.

Los niveles plasmáticos de $\mathrm{Na}^{+}, \mathrm{K}^{+}, \mathrm{Cl}^{-}, \mathrm{pCO}^{2}$ y brecha aniónica no mostraron ninguna alteración significativa $(p>0.05)$ independientemente del segmento intestinal afectado. La concentración de glucosa fue mayor en un $65 \%$ de los animales con 
Table 1. Blood gas analysis, hematocrit, hemoglobin, urea and glucose values of horses with colic syndrome classified according to the affected intestinal segment. The values are presented as mean \pm standard deviation.

\begin{tabular}{|c|c|c|c|}
\hline $\begin{array}{c}\text { Parameter } \\
\text { (reference values*) }\end{array}$ & $\begin{array}{l}\text { Small } \\
\text { intestine } \\
\text { lesions }\end{array}$ & $\begin{array}{l}\text { Large } \\
\text { intestine } \\
\text { lesions }\end{array}$ & $\begin{array}{l}\text { Control } \\
\text { (healthy } \\
\text { horses) }\end{array}$ \\
\hline $\mathbf{N}$ & 10 & 10 & 10 \\
\hline $\mathrm{Na}^{+}(132-146 \mathrm{mmol} / \mathrm{L})$ & $\begin{array}{l}136.5 \\
\pm 2.17\end{array}$ & $\begin{array}{l}135.4 \\
\pm 2.41\end{array}$ & $\begin{array}{l}134.7 \\
\pm 2.21\end{array}$ \\
\hline $\mathrm{K}^{+}(2.4-4.7 \mathrm{mmol} / \mathrm{L})$ & $\begin{array}{l}3.24 \\
\pm 0.46\end{array}$ & $\begin{array}{l}3.38 \\
\pm 0.68\end{array}$ & $\begin{array}{l}3.35 \\
\pm 0.61\end{array}$ \\
\hline $\mathrm{Cl}^{-}(96-102 \mathrm{mmol} / \mathrm{L})$ & $\begin{array}{l}98 \\
\pm 3.09\end{array}$ & $\begin{array}{l}98.6 \\
\pm 1.65\end{array}$ & $\begin{array}{l}98.9 \\
\pm 1.85\end{array}$ \\
\hline $\mathrm{pH}(7.35-7.45)$ & $\begin{array}{l}7.45 \\
\pm 0.05\end{array}$ & $\begin{array}{l}7.44 \\
\pm 0.04\end{array}$ & $\begin{array}{l}7.41 \\
\pm 0.02\end{array}$ \\
\hline $\mathrm{pCO}_{2}(38-46 \mathrm{mmHg})$ & $\begin{array}{l}45.64 \\
\pm 3.65\end{array}$ & $\begin{array}{l}44.26 \\
\pm 2.21\end{array}$ & $\begin{array}{l}42.72 \\
\pm 1.44\end{array}$ \\
\hline $\mathrm{tCO}_{2}(25-32 \mathrm{mmol} / \mathrm{L})$ & $\begin{array}{l}32.3^{\mathrm{a}} \\
\pm 5.23\end{array}$ & $\begin{array}{l}28.5^{\mathrm{b}} \\
\pm 1.90\end{array}$ & $\begin{array}{l}28.5^{\mathrm{b}} \\
\pm 1.96\end{array}$ \\
\hline $\mathrm{HCO}_{3}^{-}(22-26 \mathrm{mmol} / \mathrm{L})$ & $\begin{array}{l}31.47^{\mathrm{a}} \\
\pm 4.94\end{array}$ & $\begin{array}{l}26.79^{\mathrm{b}} \\
\pm 3.43\end{array}$ & $\begin{array}{l}23.95^{\mathrm{b}} \\
\pm 1.01\end{array}$ \\
\hline Base excess $(-4)-(+4)$ & $\begin{array}{l}7.3^{\mathrm{a}} \\
\pm 5.52\end{array}$ & $\begin{array}{l}5.9^{\mathrm{a}} \\
\pm 4.91\end{array}$ & $\begin{array}{l}2.1^{\mathrm{b}} \\
\pm 1.45\end{array}$ \\
\hline Anion Gap (6-14 mmol/L) & $\begin{array}{l}9.9 \\
\pm 2.64\end{array}$ & $\begin{array}{l}10.4 \\
\pm 2.59\end{array}$ & $\begin{array}{l}9.4 \\
\pm 2.01\end{array}$ \\
\hline Hematocrit (32-48\%) & $\begin{array}{l}43.2 \\
\pm 10.84\end{array}$ & $\begin{array}{l}42.4 \\
\pm 8.04\end{array}$ & $\begin{array}{l}38.9 \\
\pm 3.96\end{array}$ \\
\hline Hemoglobin $(11-19 \mathrm{~g} / \mathrm{dL})$ & $\begin{array}{l}14.78 \\
\pm 3.75\end{array}$ & $\begin{array}{l}14.88 \\
\pm 2.98\end{array}$ & $\begin{array}{l}12.89 \\
\pm 1.35\end{array}$ \\
\hline Urea $(23-55 \mathrm{mg} / \mathrm{dL})$ & $\begin{array}{l}47.1^{\mathrm{a}} \\
\pm 18.4\end{array}$ & $\begin{array}{l}33.1^{\mathrm{b}} \\
\pm 8.1\end{array}$ & $\begin{array}{l}36.6^{b} \\
\pm 7.7\end{array}$ \\
\hline Glucose $(75-115 \mathrm{mg} / \mathrm{dL})$ & $\begin{array}{l}157.6^{\mathrm{a}} \\
\pm 81.3 \\
\end{array}$ & $\begin{array}{l}114.5^{\mathrm{b}} \\
\pm 31.5^{5}\end{array}$ & $\begin{array}{l}94.6^{\mathrm{b}} \\
\pm 6.6\end{array}$ \\
\hline
\end{tabular}

Different letter in the same row indicates significant difference $(p<0.05)$ among groups. * Kaneko et al (5).

not show differences among all groups of horses $(p>0.05)$.

Venous blood $\mathrm{pH}$ was higher in $40 \%$ of the ECS cases than in the control animals. However, no differences in blood $\mathrm{pH}$ were found between the two groups of horses with colic syndrome $(p>0.05)$. The $\mathrm{tCO}_{2}$ was higher in horses with small intestine ECS compared to the other two groups of animals $(p<0.05)$. The bicarbonate levels were increased in $70 \%$ of the horses with colic syndrome (maximum reference value: 26 $\mathrm{mmol} / \mathrm{L}$ ). It was observed that the highest the bicarbonate value, the more severe the clinical condition of the horses. The group of horses with small bowel lesions had the highest values of bicarbonate compared to the other groups of horses $(p<0.05)$. In $60 \%$ of the animals with ECS the value of base excess was above +4 (reference value: -4 to +4 ), with higher values in the group with small bowel lesions $(p<0.05)$.

\section{DISCUSSION}

This work shows evidences of blood gas alterations in horses with colic syndrome. The blood concentration of sodium was at the reference values in all the animals of this study, ECS and control, without any difference between the two groups of horses with colic syndrome. This was also the observation of Navarro et
SCE, en comparación con los valores de referencia (valor de referencia máximo: $115 \mathrm{mg} / \mathrm{dL}$ ). Las concentraciones de glucosa y urea fueron más altas $(p<0.05)$ en el grupo de los equinos con lesiones en el intestino delgado en contraste con los animales con lesiones del intestino grueso y a los animales de control. Los valores de hemoglobina y hematocrito no evidenciaron diferencias entre todos los grupos de caballos ( $p>0.05)$.

El pH sanguíneo fue mayor en el $40 \%$ de los casos con SCE que en los animales de control. Sin embargo, no se encontraron diferencias en el pH sanguíneo entre los dos grupos de caballos con síndrome de cólico $(p>0.05)$. El valor de $\mathrm{tCO}_{2}$ fue mayor en los caballos con SCE en el intestino delgado en comparación con los otros dos grupos de animales $(p<0.05)$. Los niveles de bicarbonato se incrementaron en un $70 \%$ en los caballos con el síndrome de cólico (valor de referencia máximo: $26 \mathrm{mmol} / \mathrm{L}$ ). Se observó que entre mayor fuera el valor de bicarbonato más grave era la condición clínica de los caballos. El grupo de caballos con lesiones en el intestino delgado presentó los valores más altos de bicarbonato en relación con los otros grupos de equinos $(p<0.05)$. En el $60 \%$ de los animales con SCE el valor de exceso de base fue superior a +4 (valor de referencia: $-4 a+4$ ), con valores más altos en el grupo con lesiones en el intestino delgado $(p<0.05)$.

\section{DISCUSIÓN}

Este estudio muestra evidencias de alteraciones en los gases arteriales en caballos con cólico. La concentración sanguínea de sodio se encontraba en los valores de referencia en todos los animales de este estudio, en los grupos de SCE y de control, sin ninguna diferencia entre los dos grupos de equinos con síndrome de cólico. Esta fue también la observación que hizo Navarro et al (6), quien estudió las alteraciones electrolíticas en caballos con trastornos gastrointestinales y donde no se encontraron cambios en las concentraciones de sodio en varios tipos de lesiones intestinales. Ihler et al (7) tampoco encontraron diferencias en el sodio en la sangre al hacer una comparación entro los caballos que sobrevivieron o fallecieron debido a casos de SCE. Durante una situación clínica de SCE, la anorexia y adipsia causada por el dolor severo pueden causar una disminución del líquido extracelular acompañado de pérdida de agua en el cuerpo, aunque con una pérdida pequeña de electrolitos (8). Esto podría conducir a hipernatremia por hemoconcentración, pero no se produjo dicha situación.

Como en el presente estudio, Ferreira (8) no encontró variaciones significativas en los niveles 
al (6) who studied electrolytic alterations in horses with gastrointestinal disorders and did not find changes in sodium concentrations in several types of intestinal lesions. Ihler et al (7) also did not found differences in blood sodium comparing horses that survived or deceased in cases of ECS. During a clinical situation of ECS, anorexia and adipsia due to the severe pain might cause a depletion of extracellular fluid with loss of body water, although with small loss of electrolytes (8). This might lead to hypernatremia by hemoconcentration, but such a situation did not occur.

As in the present study, Ferreira (8) did not find significant variations in potassium levels in horses submitted to temporary fistulization at the cecum. Di Filippo et al (9) found lesser serum potassium values in horses that survived to colic syndrome compared to those that died and to the control group. That work was done with animals observed at the moment of the clinical examination, same as our study. The reduction of potassium values in colic cases may be attributed to less feed intake or to gastrointestinal losses (10).

Chloride blood levels also were not affected by the clinical condition of ECS, as in the work of Navarro et al (6). Costa et al (11) observed significant decrease in serum chloride in horses with jejunum isquemia.

Glycemia was higher in horses with lesions in the small bowel. This result was also observed by Di Filippo et al (9) who found hyperglycemia in horses that survived to a colic syndrome. In another study (12) hyperglycemia was evident in animals with induced intestinal obstruction. Hyperglycemia is a frequent finding observed in cases of ECS and is generally associated with an unfavorable prognostic (13). This is related to the high secretion of catecholamines as a consequence of excitation, pain and stress, typical episodes of ECS (14).

Urea blood concentration is regulated by two events: synthesis rate in the liver and clearance rate by kidney. Synthesis rate depends on protein intake and catabolism. Clearance rate depends on glomerular filtration rate and reabsorption activity at the renal tubules (15). In dehydration conditions, as occur in colic syndrome, glomerular filtration rate is diminished resulting in pre-renal azotemia. In the present study, urea values were higher in horses with small bowel lesions, which suggest a greater compromise in that kind of lesions. Di Filippo et al (16) did not find variations in hepatic and renal blood markers in horses submitted to experimental intestinal obstruction. In agreement with those results, de potasio en caballos sometidos a fistulización temporal en el intestino ciego. Di Filippo et al (9) encontraron valores menores de potasio en suero en los caballos que sobrevivieron al síndrome cólico en comparación con aquellos que murieron y con el grupo de control. Dicho estudio se realizó observando a los animales en el momento del examen clínico, al igual que en nuestro estudio. La reducción en los valores de potasio en casos de cólico puede atribuirse a un menor consumo de alimentos o pérdidas gastrointestinales (10).

Los niveles de cloruro en la sangre tampoco se vieron afectados por la condición clínica de SCE, como en el estudio de Navarro et al (6). Costa et al (11) observaron una disminución significativa del cloruro en suero en caballos con isquemia del yeyuno.

La glucemia fue mayor en los equinos con lesiones en el intestino delgado. Este resultado también fue observado por Di Filippo et al (9), quienes reportaron hiperglucemia en los caballos que sobrevivieron a un síndrome cólico. En otro estudio (12) se evidenció hiperglucemia en animales con una obstrucción intestinal inducida. La hiperglucemia es un hallazgo frecuente observado en casos de SCE y se asocia generalmente con un pronóstico desfavorable (13). Esto está relacionado con una alta secreción de catecolaminas como consecuencia de la excitación, el dolor y el estrés, los cuales son episodios típicos de SCE (14).

La concentración de urea en la sangre está regulada por dos eventos: la tasa de síntesis en el hígado y la tasa de eliminación por el riñón. La tasa de síntesis depende del catabolismo y de la ingesta de proteínas. Tasa de eliminación depende de la tasa de filtración glomerular y de la actividad reabsorción en los túbulos renales (15). En condiciones de deshidratación, como ocurre en el síndrome cólico, la tasa de filtración glomerular se ve reducida lo que tiene como resultado azotemia prerrenal. En este estudio, los valores de urea fueron mayores en los caballos con lesiones en el intestino delgado, lo que sugiere un mayor compromiso en ese tipo de lesiones. Di Filippo et al (16) no encontraron variaciones en los marcadores hepáticos y renales en equinos sometidos a una obstrucción intestinal experimental. De acuerdo con estos resultados, Granot et al (17) encontraron que los caballos con cólico no mostraron valores diferentes de urea en comparación con los animales que murieron o sobrevivieron. A partir de nuestros resultados sería posible considerar que los caballos con síndrome cólico causado por lesiones situadas en el intestino delgado pueden sufrir una condición más severa del desequilibrio hídrico que los caballos con afectaciones en el intestino grueso. 
Granot et al (17) found that horses with colic impaction did not have different values of urea compare to animals that died or that survived. From our results it would be probable that horses with colic syndrome caused by lesions situated at the small intestine may be suffering from a more severe condition of water imbalance than horses with compromised large intestine.

In the present study, the hematocrit values were not different between individuals with colic syndrome and control animals. An increase in the hematocrit may occur in cases of equine colic syndrome as a result of hemoconcentration, dehydration and shock (14). Datt and Usenik (18) found significant hematocrit increase in horses after 12 hours of duodenum obstruction. It seems that hematocrit elevation in gastrointestinal disorders in horses may be more frequent in most severe cases. Concomitant with the result of the hematocrit, hemoglobin values were not significantly different among the groups of animals. However, horses with colic syndrome together had hemoglobin values greater than control horses. This result is in agreement with Silva (12), who found higher hemoglobin values in horses with colic syndrome than in healthy animals. It is plausible that hemoglobin could be a more sensitive indicator than hematocrit of gastrointestinal disorders of horses $(18,19)$.

In our study, $40 \%$ of the horses with colic syndrome had increased blood $\mathrm{pH}$ in relation to the control group. Other authors also found elevated blood $\mathrm{pH}$ in horses with colon and jejunum obstructions $(11,19)$, which was associated with increased bicarbonate concentration. In the present study, the rise in blood $\mathrm{pH}$ was linked not only with higher values of bicarbonate but also with more positive values of base excess in both groups of horses with colic syndrome, especially in animals with small intestine lesions. All together $60 \%$ of the colic affected horses had base excess values above +4 , more severely when lesions occurred in the small intestine. Similar finding was observed in cases of horses with experimental intestinal obstruction (11). The $\mathrm{tCO}_{2}$ values had significant rise in horses with small bowel lesions. The $\mathrm{tCO}_{2}$ parameter expresses the alkaline reserve, with bicarbonate as its main component. A high $\mathrm{tCO}_{2}$ indicates the presence of metabolic alkalosis, and a low $\mathrm{tCO}_{2}$ indicates a metabolic acidosis (14). These increments in $\mathrm{tCO}_{2}$ and alkaline reserve in horses with small bowel lesions, were not expected in the situation of pain and stress in horses with colic, which should promote breath rate increment and decrease in $\mathrm{pCO}_{2}$ (respiratory alkalosis). In contrast with our findings, other authors found metabolic
En este estudio, los valores de hematocrito no fueron diferentes entre individuos con síndrome cólico y los animales del grupo de control. Se podría presentar un aumento en el hematocrito en casos de síndrome cólico equino como consecuencia de la hemoconcentración, deshidratación y shock (14). Datt y Usenik (18) encontraron un aumento significativo en hematocrito en los equinos 12 horas después de la obstrucción del duodeno. Parece ser que la elevación del hematocrito en trastornos gastrointestinales en caballos puede ser más frecuente en los casos más severos. De manera concomitante con el resultado del hematocrito, los valores de hemoglobina no fueron significativamente diferentes entre los grupos de animales. Sin embargo, los equinos con síndrome cólico presentaron valores de hemoglobina mayores que los caballos del grupo de control. Este resultado coincide con Silva (12), quien encontró valores más altos de hemoglobina en caballos con síndrome cólico que en animales sanos. Es plausible que la hemoglobina sea un indicador más sensible que el hematocrito para trastornos gastrointestinales en caballos $(18,19)$.

En nuestro estudio, el $40 \%$ de los caballos con síndrome cólico tenía un $\mathrm{pH}$ sanguíneo mayor en relación con el grupo de control. Otros autores también encontraron un $\mathrm{pH}$ sanguíneo elevado en caballos con obstrucciones en el colon y yeyuno $(11,19)$, lo que se asoció con una mayor concentración de bicarbonato. En el presente estudio, el aumento de $\mathrm{pH}$ en la sangre estaba vinculado no sólo con valores más altos de bicarbonato, sino también con valores más positivos de exceso de base en ambos grupos de caballos con síndrome cólico, especialmente en los animales con lesiones en el intestino delgado. El $60 \%$ de los caballos afectados por cólicos mostraron valores de exceso de base superiores a +4 , más severamente cuando las lesiones se produjeron en el intestino delgado. Se observó un hallazgo similar en casos de equinos con una obstrucción intestinal experimental (11). Los valores de $\mathrm{tCO}_{2}$ evidenciaron un aumento significativo en los caballos con lesiones en el intestino delgado. El parámetro $\mathrm{tCO}_{2}$ expresa la reserva alcalina, siendo el bicarbonato su componente principal. Un valor alto de $\mathrm{tCO}_{2}$ es indicativo de la presencia de alcalosis metabólica, y un valor bajo de $\mathrm{tCO}_{2}$ indica acidosis metabólica (14). Estos incrementos en los valores de $\mathrm{tCO}_{2}$ y la reserva alcalina en caballos con lesiones en el intestino delgado fueron inesperados en los casos de dolor y estrés en caballos con cólico, lo que debe estimular un incremento en la velocidad de respiración y una disminución de $\mathrm{pCO}_{2}$ (alcalosis respiratoria). De manera contrastante con nuestros resultados, otros autores encontraron acidosis metabólica en equinos que padecen de síndrome cólico (9), asociado con una disminución de $\mathrm{HCO}_{3}^{-}$ 
acidosis in horses suffering from colic syndrome (9), associated with a decline in $\mathrm{HCO}_{3}{ }_{3}^{-}$and base excess attributed to hipovolemia and generation of lactic acid.

The anion gap was within the reference values in $90 \%$ of the horses with colic syndrome. According to the anion gap equation $\left[\mathrm{AG}=\left(\mathrm{Na}^{+}+\mathrm{K}^{+}\right)-\left(\mathrm{HCO}_{3}^{-}+\mathrm{Cl}^{-}\right)\right]$the $\mathrm{AG}$ values should be diminished, because the term $\mathrm{HCO}_{3}{ }^{-}$is augmented and sodium, potassium and chloride did not have alterations, as it was showed in our work. More research should be done to evaluate if there are other anion alterations in cases of equine colic syndrome.

In conclusion, horses with colic syndrome do not show significant alterations in plasma electrolytic parameters $\left(\mathrm{Na}^{+}, \mathrm{K}^{+}, \mathrm{Cl}^{-}\right)$or in the levels of $\mathrm{pCO}_{2}$ and anion gap, independently of the intestinal location of the lesion. Horses with small bowel lesions have higher values of $\mathrm{tCO}_{2}, \mathrm{HCO}_{3}^{-}$, base excess, urea and glucose than horses with large bowel lesions, suggesting a condition of metabolic alkalosis and more severe stress. y exceso de base atribuido a hipovolemia y a la generación de ácido láctico.

La brecha aniónica se encontraba dentro de los valores de referencia en el $90 \%$ de los caballos con síndrome cólico. De acuerdo con la ecuación de la brecha aniónica $\left[\mathrm{BA}=\left(\mathrm{Na}^{+}+\mathrm{K}^{+}\right)-\left(\mathrm{HCO}_{3}+\mathrm{Cl}^{-}\right)\right]$. Los valores de $\mathrm{BA}$ deben ser disminuidos porque el término $\mathrm{HCO}_{3}{ }^{-}$se ha incrementado y no se presentaron alteraciones en los valores de sodio, potasio y cloruro, como se demostró en nuestro estudio. Se debe efectuar una mayor investigación para evaluar si existen otras alteraciones aniónicas en casos de síndrome cólico equino.

En conclusión, los equinos con síndrome cólico no mostraron alteraciones significativas en los parámetros de electrolítico plasmático $\left(\mathrm{Na}^{+}, \mathrm{K}^{+}, \mathrm{Cl}^{-}\right)$ o en los niveles de $\mathrm{pCO}_{2}$ y la brecha aniónica, independientemente de la ubicación de la lesión intestinal. Los caballos con lesiones en el intestino delgado mostraron valores más elevados de $\mathrm{tCO}_{2}$, $\mathrm{HCO}_{3}{ }^{-}$, exceso de base, urea y glucosa que los equinos con lesiones en el intestino grueso, lo que sugiere una condición de alcalosis metabólica y estrés más severo.

\section{REFERENCES}

1. Nappert G, Johnson PJ. Determination of the acid-base status in 50 horses admitted with colic between December 1998 and May 1999. Canadian Vet J 2001; 42:703-707.

2. Nolen-Walston R, Paxson J, Ramey DW. Evidence-based gastrointestinal medicine in horses: It's not about your gut instincts. Vet Clin North Am Equine Pract 2007; 23:243-266.

3. Alves GES, Ribeiro Filho JD, Oliveira HP, Abreu JMG. Tratamento da compactação experimental do cólon maior em eqüinos: resultados de laboratório e exames bioquímicos. Arq Bras Med Vet Zootec 2005; 57:281-287.

4. Gokce G, Citil M, Gunes V, Atalan G. Effect of time delay and storage temperature on blood gas acid-base values of bovine venous blood. Res Vet Sci 2004; 76:121-127.

5. Kaneko JJ, Harvey JW, Bruss ML. (Eds.). Clinical Biochemistry of Domestic Animals. 6.ed. San Diego: Academic Press, 2008.
6. Navarro M, Monreal L, Segura D, Armengou $L$, Añor $S$. A comparison of traditional and quantitative analysis of acid-base and eletrolyte imbalances in horses with gastrointestinal disorders. J Vet Inter Med 2005; 19(6):871-877.

7. Ihler CF, Venger JL, Skjerve E. Evaluation of clinical and laboratory variables as prognostic indicators in hospitalised gastrointestinal colic horses. Acta Vet Scand 2004; 45(1-2):109-118.

8. Ferreira FPP. Fistulização temporária do ceco em eqüinos: estudo experimental da técnica cirúrgica e da viabilidade desta via para a administração de fluído enteral. [Tese de Doutorado]. Botucatu: Universidade Estadual Paulista. Programa de Pós-graduação em Cirurgia Veterinária, 2006.

9. Di Filippo PA, Santana AE, Pereira GT. Equilíbrio ácido-base e hidroeletrolítico em eqüinos com cólica. Ciência Rural 2008; 38(4):1003-1009.

10. Toribio RE. Essentials of equine renal and urinary tract physiology. Vet Clin North Am Equine Pract 2007; 23(3):533-561. 
11. Costa NS, Ribeiro G, Dória RGS, Canola PA, Silva PC, Jorge RLN et al. Hemograma e hemogasometria de equinos submetidos a obstrução experimental de jejuno. Arq Bras Med Vet Zootec 2008; 60(6):1367-1374.

12. Silva CF. Valores hematológicos bioquímicos e exame do líquido peritoneal de eqüinos (Equus caballus, Linnaeus, 1758) durante síndrome cólica. [Dissertação de Mestrado]. Botucatu: Universidade Estadual Paulista. Faculdade de Medicina Veterinária e Zootecnia, 2005.

13. Marr CM. On the question of colic: are answers beginning to emerge?. Equine Vet J 2012; 44(4):384-386.

14. McGowan C. Clinical pathology in the racing horse: the role of clinical pathology in assessing fitness and performance in the racehorse. Vet Clin North Am Equine Pract, $2008 ; 24(2): 405-421$.

15. Stockham SL. Interpretation of equine serum biochemical profile results. Vet Clin North Am Equine Pract 1995; 11(3):391-414.
16. Di Filippo PA, Pereira RN, Perotta JH, Berlingieri MA, Freitas FC, Santana AE. Variações nas concentrações dos biomarcadores sanguíneos da função renal e hepática em equinos submetidos a obstrução experimental do duodeno, íleo e cólon maior. Ciência Animal Bras 2011; 12(1):178-186.

17. Granot N, Milgram J, Bdolah-Abram T, Shemesh I, Steinman A. Surgical management of sand colic impactions in horses: a retrospective study of 41 cases. Australian Vet J 2008; 86(10):404-407.

18. Datt SC, Usenik EA. Intestinal obstruction in the horse. Physical signs and blood chemistry. Cornell Vet 1975; 65:152-172.

19. Di Filippo PA. Obstrução intestinal experimental em equinos: parâmetros clínicos e laboratoriais. [Tese de Doutorado]. Jaboticabal: Universidade Estadual Paulista. Faculdade de Ciências Agrárias e Veterinárias, 2009. 